$$
\begin{aligned}
& \text { دراسة وجود السليكا في المواد الخام الأولية لمقالع } \\
& \text { معمل أسمنت حمام العليل }
\end{aligned}
$$

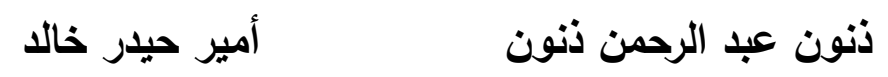

$$
\begin{aligned}
& \text { قسم علوم الأرض } \\
& \text { كلية العلوم }
\end{aligned}
$$

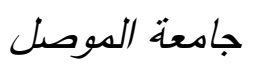

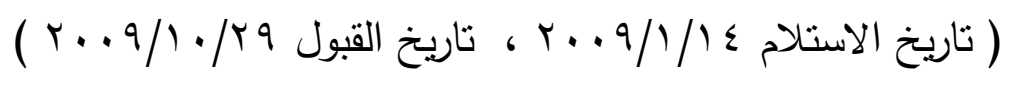

تم دراسة طبيعة وتوزيع السليكا الحرة ومعرفة محتواها ومديات حجومها في المواد الخام لمقالع معطل اسمنت حمام العليل، والمتمنلة بالصخور الجيرية والأطيان لمنطقتي طقطق ومشيرفة المستغلة حالياً في صناعة الأسمنت. كما نتاول البحث تقييم الصخور الجيرية والأطيان لمنطقتي طويبة وجهوني كمواد بديلة بهدف خفض محتوى السليكا والمعامل السليكي وتحسين خواص الكلنكر . دلت المعطيات الكيميائية والمعدنية والنسيجية على ارتفاع محتوى السليكا في كل من الصخور الجيرية والأطيان للمقالع المستغلة، إذ توجد

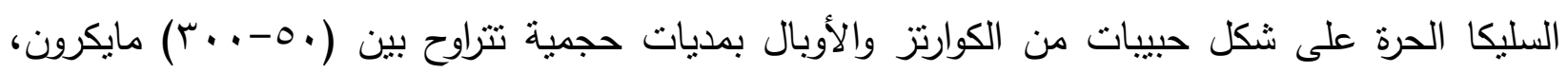
بينما يقل محتوى السليكا الكلية عن (3.5\%) في الصخور الجيرية لمنطقة طويبة.

\title{
Study of Silica Occurrence in the Raw Materials of Hammam Al- Alil Cement Plant
}

Thanoon A. Thanoon

Department of Geology

College of Science

Mosul University

\section{Ameer H. Khalid}

\section{ABSTRACT}

Investigations of the nature, distribution, contents and size of free silica in the raw materials currently quarried and used at Hammam Al-Alil Cement Plant have been carried out. The raw materials are limestones and clays, being extracted from Taqtaq quarry and Mshirfa valley. Limestones and clays from Tweba and Jahuni areas have been assessed in order to be used as substitute materials for the purpose 
ذنون عبد الرحمن ذنون و أمير حيدر خالد

of lowering silica content, silica ratios and improving clinker properties. Chemical, mineralogical and textural examinations revealed that the silica contents are high in the currently quarried limestones and clays, while it is rather low in limestones from Tweba area. The free silica is represented as quartz and opal grains, ranging in size between (50-300) microns. 